\section{Biolumineszenz im klinisch-chemischen Labor}

W. Stöcker und W. Schlumberger

Euroimmun Medizinische Labordiagnostika AG, Lübeck, Deutschland

Synonym(e) Luciferin-System

\section{Englischer Begriff bioluminescence}

Definition Die Biolumineszenz spielt als Detektionssystem bei biochemischen und immunologischen Nachweisen eine große Rolle. Ein Luciferin wird in Gegenwart von Sauerstoff und einem artspezifischen Enzym, der Luciferase, unter Energieverbrauch in ein aktiviertes Oxyluciferin umgewandelt, das zur Lichtabgabe befähigt ist. Diese Reaktion findet man z. B. bei Glühwürmchen, Pflanzen und Einzellern der Tiefsee. Die Lichtausbeute beträgt bis zu 90 \%. Die Biolumineszenz zeichnet sich durch eine hohe Sensitivität und ein niedriges Hintergrundsignal sowie einen großen Linearitätsbereich aus.

Beschreibung Bekannteste Anwendungsbeispiele für die Biolumineszenz im klinisch-chemischen Labor sind:

- Reportergen-Assays: Das Luciferasegen wird in die Nachbarschaft der Test-DNA eingesetzt und mit ihr zusammen abgelesen. Das emittierte Licht ist ein Maß für die Expression des entsprechenden eukaryontischen DNAAbschnitts.

- Vitalitätstest: Da Adenosintriphosphat (ATP) als universeller Energieträger für den Ablauf der Luciferasereaktion benötigt wird, ist die Lichtemission ein Maß für die ATPProduktion in lebenden Zellen.

- Immunoassays: Markierung von Antigenen (s. - Antigen) und Antikörpern (s. - Antikörper), die durch Luciferasewirkung eine messbare Lumineszenz erzeugen. 